RESEARCH ARTICLES

\title{
Innovative human capital management of energy enterprises and the role of shaping the environmental behavior of consumers of green energy based on the work of smart grids
}

\section{Gestión innovadora del capital humano de las empresas energéticas y el papel de dar forma al comportamiento medioambiental de los consumidores de energía verde a partir del trabajo de las redes inteligentes.}

Galyna Liakhovych

Doctor of Economic Sciences, Department of Management and Administration. West Ukrainian National University, Ternopil, Ukraine. ORCID 0000-0002-0077-9128

Volodymyr Kupchak

Doctor of Economic Sciences, Professor, Department of Management and Administration. West Ukrainian National University, Ternopil, Ukraine. ORCID 0000-0003-1791-5381

Olena Borysiak

$\mathrm{PhD}$ in Economics, Marketing Department West Ukrainian National University, Ternopil, Ukraine. ORCID 0000-0003-4818-8068

Oksana Huhul

$\mathrm{PhD}$ in Economics, Department of Management and Administration. West Ukrainian National University, Ternopil, Ukraine. ORCID 0000-0003-3052-5759

Nataliya Halysh

PhD in Economics, Department of International Tourism and Hospitality Business, West Ukrainian National University, Ternopil, Ukraine. ORCID 0000-0002-8538-823X

Vasyl Brych

Doctor of Economic Sciences, Professor, Department of International Tourism and Hospitality Business West Ukrainian National University. Ternopil, Ukraine. ORCID 0000-0002-4277-5213

Mariana Sokol

Doctor of Pedagogical Sciences, Professor, Romanic-German Philology Department, Ternopil Volodymyr Hnatiuk National Pedagogical University. Ternopil, Ukraine. ORCID ID 0000-0003-3876-026X

Received 09-08-20 Revised 10-10-20

Accepted 20-12-21 On line 03-17-21

* Correspondence 


\section{Summary}

The use of Internet of Things programs in various fields of activity testifies the reset of the human lifestyle. Climate change and limited access to natural resources are factors for shaping the environmental behavior of energy consumers. Ensuring the development of Smart specialization and innovation in the energy sector provides the transformation of a set of competencies and skills, the organization of the workspace based on digitalization, as well as the increasing role of continuous personnel training at energy enterprises. Considering this, the article is devoted to the development of a system of innovative human capital management of energy enterprises in the context of environmental behavior formation of consumers of green energy based on the work of Smart Grids, the solution of the issue of identification and the formation of appropriate digital competencies to optimize the process of marketing promotion of green energy services in the virtual space. For this, the role of human capital formation in the innovative development of an energy enterprise and the approval of the foundations for organizing a virtual socio-economic space based on the work of smart grids.The relationship between the formation of environmental behavior of consumers of green energy and the need to develop digital competencies of employees of energy enterprises has been proved. The level of the use of innovative technologies for the development of personnel in the field of energy has been investigated and a set of digital competencies necessary for the development of the industry in the conditions of the formation of environmental behavior of consumers of green energy based on the operation of Smart Grids has been established. The analysis of the dynamics of the use of computers, computer networks, and social media at Ukrainian enterprises by types of economic activity indicates an increase in the level of use of social media and mobile networks. The algorithm for managing the human capital of energy enterprises in the virtual space has been optimized for the formation of digital competencies based on the work of Smart Grids, which will contribute to ensuring the transition to an increase in the consumption of green energy.

Key words: human capital, energy services, smart grids, virtual enterprises, smart specialization, sustainable development, innovation, digital technologies, information society, long life learning, innovative learning technologies.

\section{Resumen}

El uso de programas de Internet de las cosas en varios campos de actividad atestigua el restablecimiento del estilo de vida humano. El cambio climático y el acceso limitado a los recursos naturales son factores que configuran el comportamiento medioambiental de los consumidores de energía. Asegurar el desarrollo de la especialización e innovación inteligente en el sector energético proporciona la transformación de un conjunto de competencias y habilidades, la organización del espacio de trabajo basada en la digitalización, así como el papel cada vez mayor de la formación continua del personal en las empresas energéticas. Teniendo esto en cuenta, el artículo está dedicado al desarrollo de un sistema de gestión del capital humano innovador de las empresas energéticas en el contexto de la formación del comportamiento ambiental de los consumidores de energía verde basado en el trabajo de las Smart Grids, la solución del problema de identificación y la Formación de competencias digitales adecuadas para optimizar el proceso de promoción de marketing de servicios de energía verde en el espacio virtual. Para ello, el papel de la formación de capital humano en el desarrollo innovador de una empresa energética y la aprobación de las bases para la organización de un espacio socio-económico virtual basado en el trabajo de las redes inteligentes. Se ha demostrado la energía verde y la necesidad de desarrollar las competencias digitales de los empleados de las empresas energéticas. Se ha investigado el nivel de uso de tecnologías innovadoras para el desarrollo de personal en el campo de la energía y se ha investigado un conjunto de competencias digitales necesarias para el desarrollo de la industria en las condiciones de formación del comportamiento ambiental de los consumidores de energía verde basado en Se ha establecido el funcionamiento de Smart Grids. El análisis de la dinámica del uso de computadoras, redes informáticas y redes sociales en las empresas ucranianas por tipo de 
actividad económica indica un aumento en el nivel de uso de las redes sociales y las redes móviles. El algoritmo de gestión del capital humano de las empresas energéticas en el espacio virtual ha sido optimizado para la formación de competencias digitales basadas en el trabajo de Smart Grids, lo que contribuirá a asegurar la transición hacia un incremento en el consumo de energía verde.

Palabras clave: capital humano, servicios energéticos, redes inteligentes, empresas virtuales, especialización inteligente, desarrollo sostenible, innovación, tecnologías digitales, sociedad de la información, aprendizaje a lo largo de la vida, tecnologías de aprendizaje innovadoras.

\section{Introduction}

Rapid information acquisition, the need for operational analysis of large databases (Big Data) and the possibility of multi-channel communication form a "smart" work environment and "smart" leisure time. Under such conditions, the physical or intellectual performance of tasks by a person is integrated with the work of artificial intelligence through the digitalization of business processes and working conditions.

As a result, the actual question for a specialist in the relevant field is the mastery of the working skills with programs of the Internet of Things (IoT) through prompt access to educational programs. In addition, virtual organizations are considered as forms of cooperation of joint work resources from different geographic locations for the implementation of common goals, which are performed by personnel in accordance with the existing competence (Merkevicius J., 2015. p. 202). J. Vveinhardt and R. Minkute-Henrickson note the process of transformation of an organization that learns into a rational organization, because the continuity of the process of training and personnel development directly affects the implementation of higher corporate goals (Vveinhardt J., 2015).

Taking this into account, there is a shift in priority from physical labor to intellectual labor and, as a consequence, an increase in the role of investment in human capital. This is of particular importance for the energy industry, which monitors the strengthening of energy efficiency and energy conservation policies through the transition to the use of Smart technologies and Grid technologies in the management of production, supply and consumption of green energy.

Considering the dynamic development of e-commerce, the Internet of Things and, as a consequence, the increasing role of cybersecurity, the confidentiality of energy planning for energy service companies based on the energy blockchain network is proposed. This method also contributes to environmental protection and transparent planning of companies in a virtual environment. In addition, such a blockchain network can display information on energy demand and supply to improve data privacy and security (Brych V., 2020)

In addition, the approval of 17 Sustainable Development Goals by the UN General Assembly in 2015 laid the foundation for the transformation of the organization of processes in various spheres of human life for the period up to 2030. In particular, it is envisaged to ensure access to affordable, reliable, sustainable and modern energy sources for all, which, in turn, will contribute to the growth of the role of shaping the environmental behavior of consumers of green energy.

Ensuring the approval of the foundations of municipal ecology provides the transition to environmentally friendly modes of transport. The study (Lokhandwala M., 2020) noted that the transport sector is experiencing three revolutions: general mobility, autonomous driving and electrification. Accordingly, a framework is proposed to optimize the design of a charging infrastructure to increase the acceptance rate of an electric vehicle in systems with different levels of autonomous vehicle acceptance and participation in co-driving (Lokhandwala M., 2020). 
As a result, to ensure the formation of environmental behavior among consumers of green energy, it is necessary to have a complex of both soft skills and digital skills. According to the research conducted by LinkedIn Learning to determine the most necessary skills in 2020 (Navyky, 2020), it is identified that along with creativity, collaboration, persuasiveness, emotional intelligence, sales management, affiliate marketing, there is the need to develop skills such as work on blockchain, cloud technologies, artificial intelligence, the use of digital technologies in the implementation of business intelligence, UX design, video content production, etc. It has been established the positive influence of the development of strategic emotional intelligence on organizational learning, growth and how strategic emotional intelligence models the relationship between technological capabilities, technological knowledge management, learning and organizational growth (Nanayakkara S.M., 2018)

On the other hand, the development of IoT programs presupposes the fusion of physical things from the Internet, i.e. the minimization of physical contacts between a person and a thing in order to perform the corresponding operation, in particular, the development of smart houses. Accordingly, the development of smart competencies of employees of energy enterprises is of great importance. Indeed, given the trends in the development of smart specialization, including the emergence of intelligent energy houses and the need to develop smart competencies, proposes a human data model using a cyber-physically social approach, where the virtual world and the physical world merge with each other, and the social world crosses the physical and virtual worlds, reflecting social relations and interactions.

To ensure the development of digital technologies and the need for lifelong learning by investing in the formation of human capital in the higher education system of the member states of the European Union, it is highlighted the transition from the concepts of "University of Teaching" to "University of Learning", the introduction of new digital technologies into the educational space (online storytelling, Internet conferences, wiki projects, educational games, augmented reality (Buchynska T. M., 2019 p. 4). In turn, the introduction of training programs on the use of smartphones for the elderly and children is of great importance, aimed at increasing digital competence and the life quality of the population.

The relevance of the digital competencies formation is complemented by the decision of the European Union on the introduction and financing of the EU4Digital program (Prohrama EU4), which is aimed at supporting the implementation of digital skills strategies in the Eastern Partnership countries. The goal of this program is to form national coalitions to create digital jobs and develop digital competencies of specialists, to promote the development of small and mediumsized enterprises.

\section{Problem statement in general}

The conducted review of scientific works testifies to the relevance of creating an environment for the development of digital competencies in the energy sector and the need for innovative management of the human capital of energy enterprises engaged in the production and supply of green energy. It is important to establish the relationship between the development of soft skills and the formation of digital competencies in the context of the development of the Internet of Things. In turn, the need to optimize the process of identification and development of relevant digital competencies among employees of energy enterprises predetermine the optimization of the algorithm for managing the human capital of energy enterprises, which will contribute to the formation of environmental behavior of consumers of energy services and ensure the transition to the consumption of green energy.

The aim of the article is to improve the system of innovative human capital management of energy enterprises in the context of the formation of environmental behavior of consumers of green energy based on the work of Smart Grid, to address the issue of identification and formation of appropriate digital competencies to optimize the process of marketing promotion of green energy services in the virtual space. 
The relationship between the formation of environmental behavior of consumers of green energy and the digitalization of production and supply processes of energy enterprises based on the work of Smart Grids. By 2050 in the US, $80 \%$ of jobs will be computerized in the automotive industry, $70 \%$ - in the plastics industry, $60 \%$ - in security and defense, $45 \%$ - in medicine and healthcare, $30 \%$ - in the tourism industry, and according to the Brussels European Global Economic laboratories in different countries, regardless of the level of development, 50-60\% of professions can be replaced by new technologies (Buchynska T. M., 2019. p. 8).

It has been found that regional gross value added (GVA) improves significantly if there is a combination of professions in the regions, which includes what we define as smart workers: these are workers employed in progressive production and bearing production support( Mariachiara Barzotto., 2019). In addition, with the development of digital technologies and the ability to work remotely, enterprises are practicing switching to a 4-day work week and a 6-hour work day, which contributes to achieving a balance between work and rest, increasing the level of staff motivation and the desire to develop.

Within the framework of the prevention of climate change, the main goal of the European Union is to reduce the anthropogenic impact on the environment by reducing $\mathrm{CO} 2$ emissions by $60 \%$ by 2050 compared to 1990 . Electric vehicles are a type of clean form of transportation that is powered by alternative sources such as wind and photovoltaic solar energy. However, charging large electric parks poses a danger to the grid, as the growing demand for electric stations can overvolt local transformer stations and increase the price of electricity. The sources of electricity supply are the households of the agents and the service industry (governments, shops, hospitals, schools, etc.). For example, in the Netherlands, car refueling is carried out mostly in private battery stations (Van Der Kam., 2019).

According to the Ukrainian Manufacturers Association "Ukravtoprom", during JanuarySeptember 2019, 5081 electric cars were registered in Ukraine, which is $42 \%$ more compared to the same period in 2018; and 397 commercial electric vehicles double the number in 2018. But the dynamics of the number of filling stations for electric vehicles in Ukraine increased from 600 in 2016 to 1000 in 2018. Taking this into account, there are 5-8 electric car users per 1 filling station for electric vehicles in Ukraine.

In addition, it is worth paying attention to the fact that, in accordance with the forecast data (Infographic guide "Energy of Ukraine",2020) in 2040, half of the world's energy will be consumed in the form of electricity (Table 1). According to forecasts of the Ministry of Energy and Environmental Protection of Ukraine, the implementation of the Concept of green energy transition of Ukraine by 2050 provides the transition to environmentally friendly transport by using $70 \%$ of renewable energy sources in electricity generation, the introduction of smart grids and a reduction to $0 \%$ of the share coal-fired heat and power plants in the power industry (Infographic guide "Energy of Ukraine”,2020).

Table 1. Forecast of the structure of energy consumption in the world by fuel type, per cent

\begin{tabular}{|c|c|c|c|}
\hline $\begin{array}{c}\text { Type of energy } \\
\text { Renewable energy } \\
\text { sources }\end{array}$ & 2017 & 2040 & $\begin{array}{c}\text { Deviation between 2040 } \\
\text { and 2017 }\end{array}$ \\
\hline gas & 4 & 15 & +11 \\
\hline hydropower & 23 & 26 & +3 \\
\hline atomic energy & 7 & 7 & 0 \\
\hline oil & 34 & 4 & -7 \\
\hline coal & 28 & 27 & -8 \\
\hline
\end{tabular}

Source: (Infographic guide "Energy of Ukraine", 2020) 
Considering such forecast data, let us consider the dynamics of electricity production and consumption in Ukraine. In total, in terms of data (Table 2) during 2014-2018 in Ukraine, we are tracking the positive dynamics of electricity production from renewable sources (wind, solar, hydroelectric power plants, biofuels and waste). According to Information note on the main indicators of the development of industries of the fuel and energy complex of Ukraine in 2019, the volume of electricity production by power plants that are part of the United Energy System of Ukraine reached 153964.8 million $\mathrm{kWh}$, which is 5385.8 million $\mathrm{kWh}$ or $3.4 \%$ less than in 2018 year. However, in 2019, the production of electricity by renewable energy sources (wind power plant, solar power plant, biomass) increased by 2909.6 million KWh or $110.5 \%$ compared to 2018 and amounted to 5542.3 million KWh.

The analysis of the dynamics of electricity production indicates the environmental behaviour formation of consumers of green energy. In addition, it is advisable to note that the European Green Agreement, adopted by the European Commission in December 2019, approved a course for climate neutral development of the economy and society until 2050 and at the same time became another reboot of the energy policy of states aimed at preserving the environment and prevention of climate change. In particular, in Ukraine, which supported the implementation of this agreement provisions, the Concept of Ukraine's green energy transition by 2050 was adopted. According to the Concept, among the set of measures, digitalization and technological changes in energy supply and distribution systems are envisaged (launch of smart grids).

Table 2. Dynamics of the production level of various types of energy in Ukraine during 2014-2018, thousand tons of oil equivalent

\begin{tabular}{|c|c|c|c|c|c|c|}
\hline $\begin{array}{c}\text { Type of } \\
\text { energy }\end{array}$ & 2014 & 2015 & 2016 & 2017 & 2018 & $\begin{array}{c}\text { Deviation } \\
\text { between } \\
2018 \text { and } \\
2014\end{array}$ \\
\hline Coal and peat & 31891 & 17423 & 22869 & 13696 & 14087 & -17804 \\
\hline Crude oil & 2817 & 2618 & 2304 & 2208 & 2341 & -476 \\
\hline $\begin{array}{c}\text { Petroleum } \\
\text { products }\end{array}$ & - & - & - & - & - & - \\
\hline Natural gas & 15022 & 14814 & 15175 & 15472 & 16487 & 1465 \\
\hline $\begin{array}{c}\text { Atomic } \\
\text { energy }\end{array}$ & 23191 & 22985 & 21244 & 22449 & 22145 & -1046 \\
\hline Hydropower & 729 & 464 & 660 & 769 & 897 & 168 \\
\hline $\begin{array}{c}\text { Wind energy, } \\
\text { solar energy }\end{array}$ & 134 & 134 & 124 & 149 & 197 & 63 \\
\hline $\begin{array}{c}\text { Biofuels and } \\
\text { waste }\end{array}$ & 2399 & 2606 & 3348 & 3575 & 3726 & 1327 \\
\hline $\begin{array}{c}\text { Electricity } \\
\text { Heat energy }\end{array}$ & - & - & - & - & - & - \\
\hline
\end{tabular}

Source: (Energy balance of Ukraine, 2012).

As a result, the innovative development of energy enterprises is determined by the rate of renewal of corporate knowledge, the level of development of dynamic abilities within the framework of ensuring the digitalization of business processes. An essential feature of the new "network" society is the removal or weakening of social control and coercion, since interaction in virtual reality makes it difficult or even impossible for social control, information turns into communication and, accordingly, into a product (Zvarych R. Y., 2018 p. 80-81).

In addition, the key global trends in the development of e-commerce are the following: globalization and blurring of borders; Big Data (according to IDC, the market for big data technologies will grow 6 times faster than the entire IT industry; in 2017 the volume of this market amounted to 35 billion euros); personalization (adaptation of the online store, product offers, prices for a specific user, at the moment visited the site); omnichannel (providing a company with a single price, reliable and up-to-date information about goods in all sales channels, providing customers with the opportunity to choose the most convenient way of communication; Internet 
Marketing; the transition of retail to online; application of innovative payment methods; activation of the development of mobile payment systems; investing in logistics activities and delivery of services in the segment of servicing regional buyers; formation and development of online platforms as intermediaries in e-commerce; development of cross-border online commerce(. Trushkina N. V.)

Taking this into account, an urgent issue is the restructuring of the organizational structure of enterprise management based on a network, i.e. virtualization of social and labor relations, in which operational processes of information dissemination (explicit knowledge) and its decodification by a person take place, as a factor of influence into new knowledge (Brych V., 2017 p. 175). The use of digital technologies in the human capital management system of energy enterprises is aimed at optimizing the process of production and supply of energy, as a result, it will help to reduce costs, prevent risks and increase the efficiency of using human capital.

At the same time, the organization transformation of production processes of energy enterprises based on the launch of smart grids indicates the need to create conditions for the development of workers along with soft skills (emotional intelligence, creativity, teamwork, flexibility, critical thinking, time management, etc.), as well as digital competencies. In this context, it is worth noting the fact that before launching a virtual organization, the personnel management functions should be adapted to the software features of technological systems, because the source of identification of departments, in particular the virtual personnel management department, is the employees' media connection located in other departments and in different territories. At the same time, the typical employee subordination of the virtual department to two managers (line and personnel manager) is preserved (Kachaňáková, A., 2011 p. 24-25).

The development of "soft skills" lays a springboard for the formation of digital competencies. As a result, in the context of the approval of Smart-specialization of business processes of energy enterprises and the development of the Internet of Things in the energy sector, the need for systematization of technologies for the formation of relevant competencies increases.

Condition transformation of the human capital formation of energy enterprises within the development of Smart specialization and innovation in the energy sector. The desire of enterprises to assert their positions in the virtual business environment leads to a change in the approach to defining the role of human capital in making a profit for an enterprise. Innovative human capital is seen as a combination of a human being and innovation, as the core of the regional economy. According to the Global Talent Trends 2020 report from LinkedIn, the formation of the competitiveness of enterprises will be influenced by such factors as employee experience, people analytics, internal recruiting, and multigenerational workforce.

In particular, innovation policies include strengthening the skills of the workforce and increasing the incentives of the firm's management to innovate. Indicators of human capital include the number of highly educated employees in general, education and ownership of the manager, education and age of the management team. The results show that more highly educated employees lead not only to more patent applications, but also to a greater likelihood of innovation.

On the other hand, it is interesting to determine the influence of labor market institutions on the diversity of human skills development. It has been found that unemployment protection encourages diversity by reducing the risk burden of a wide range of training or human capital investment; for this reason, institutions to support the unemployed encourage innovation. At the same time, employment protection reduces the need for training. For this reason, it does not promote diversity and can actually suppress overall diversity and innovation (Filipiletti A., 2020).

In the context of the development of the Internet of Things, the creation of virtual enterprises, the approach to defining the concept of innovation is changing. It was found that innovations can arise regardless of the activity type of the enterprise and its location. Such 
innovations are called latent innovations that arise in local economies as a result of intersectoral sales and purchases, as well as spatial proximity (large latent innovation activity is tracked in a district in which employment is growing, while the dynamics of the number of patents is negative). In addition, the development of digital technologies and the digitalization of business processes create conditions for changing the form of work organization through the transition to distance employment, and this, in turn, indicates the need for the formation of digital competencies in employees and customers.

In the context of the organization of production and supply processes of energy based on the work of smart grids to determine the role of human capital, the need for the formation of digital competencies in the energy sector, an analysis was made of the level of implementation of digital technologies, in particular, the coefficients of modernization of computer facilities and software (Table 3), as well as a survey among managers of three energy enterprises (oblenergo enterprises of Ukraine: OJSC "Ternopiloblenergo", CJSC "Rivneoblenergo", CJSC "Lvivoblenergo"). In the context of the data in Table 3, it was traced negative dynamics regarding the modernization process of computer facilities and software, including on the basis of the work of smart grids. But as a result of the interview, it was revealed that an important factor in the competitiveness of the enterprise, the formation of loyalty to the brand of the enterprise is the introduction of technologies for the development and motivation of personnel, based on innovative achievements in the field of digital information technologies. In this context, it was established that it is necessary to focus on employees who are creative and who are interested in development trends both in their specialty and in related areas, and who are ready to use remote forms of labor organization, to conduct training to improve the digital literacy of employees.

Table 3. Coefficients of modernization of computer facilities and software at energy enterprises

\begin{tabular}{|c|c|c|c|c|c|}
\hline & 2016 & 2017 & 2018 & 2019 & $\begin{array}{c}\text { Deviation } \\
\text { between } 2019 \\
\text { and } 2016\end{array}$ \\
\hline OJSC "Ternopiloblenergo" & 0,03 & 0,025 & 0,01 & 0,02 & $-0,01$ \\
\hline CJSC "Rivneoblenergo" & 0,03 & 0,02 & 0,03 & 0,02 & $-0,01$ \\
\hline CJSC "Lvivoblenergo" & 0,01 & 0,03 & 0,03 & 0,03 & 0 \\
\hline
\end{tabular}

Source: (Investment programs of PJSC "Rivneoblenergo", 2012; Investment programs of OJSC "Ternopiloblenergo", 2012).

Taking this into account, through employees' questionnaires and interviews of the surveyed enterprises, an assessment was made of the use level of technologies for the development of soft skills in employees and the formation of digital competencies in the context of the development of the Internet of Things. It was found that enterprises often use traditional technologies for personnel formation (for example, mentoring - 98\% of all surveyed enterprises; however, coaching $-7 \%$, gamification $-2 \%$, headhunting $-2 \%$ ). On the other hand, there was a positive trend in the introduction of digital technologies in the organization of personnel labor, which, in turn, necessitates an increase in the digital literacy of employees. In particular, among digital competencies employees are ready to develop, it was noted (Table 4) both digital professional competencies (working with digital communication channels, digital business analytics) and digital competencies which are necessary in everyday life (smart home, smart transport, e-health, online shopping, etc.).

Table 4. Promising educational areas for the formation of digital competencies as components of the information society development

\begin{tabular}{|c|c|}
\hline \multicolumn{2}{|c|}{ Digital competences } \\
\hline - blockchain & - digital communication channels \\
\hline - digital business intelligence, Big Data & - Artificial Intelligence \\
\hline - Web site & - Internet of Things \\
\hline - digital business communication, email & - $\quad$ social media: social networks, blog \\
\hline - e-health & - $\quad$ smart transport \\
\hline - virtual excursions & - $\quad$ smart house \\
\hline
\end{tabular}




\begin{tabular}{|c|c|}
\hline - intelligent energy & - online stores \\
\hline - management of Smart Grids & - full time employment and training \\
\hline - wireless access, mobile connection & - e-commerce \\
\hline - $\quad$ social media marketing $(\mathrm{SMM})$ & - $\quad$ site optimization (SEO) \\
\hline
\end{tabular}

Source: formed on the basis of our own research

However, in order to understand the importance of the peculiarities of the information society development and the importance of innovative management of human capital through the formation of digital skills, an analysis of the use level of digital technologies in the enterprises activities was carried out (Table 5).

Table 5. Dynamics of the use level of computers, computer networks, social media at Ukrainian enterprises by the type of economic activity, percentage of the total number of enterprises

\begin{tabular}{|c|c|c|c|c|}
\hline \multirow[t]{2}{*}{ indicator } & \multicolumn{4}{|c|}{ year } \\
\hline & 2015 & 2017 & 2018 & $\begin{array}{l}\text { Deviation } \\
\text { between } 2018 \\
\text { and } 2015\end{array}$ \\
\hline $\begin{array}{l}\text { used computers in the total number of surveyed } \\
\text { enterprises }\end{array}$ & 95,2 & 95,4 & 95,5 & +0.3 \\
\hline $\begin{array}{l}\text { had access to the Internet in the total number of } \\
\text { enterprises that used computers }\end{array}$ & 97,9 & 98,2 & 98,1 & $+0,2$ \\
\hline $\begin{array}{l}\text { had a website in the total number of businesses with } \\
\text { Internet access }\end{array}$ & 44,4 & 41,0 & 51,6 & $+0,12$ \\
\hline $\begin{array}{c}\text { social media (Facebook, LinkedIn, Xing, Viadeo, } \\
\text { Yammer, etc.) }\end{array}$ & 17,5 & 26,7 & 28,5 & +11 \\
\hline $\begin{array}{c}\text { enterprise blogs or microblogging (Twitter, } \\
\text { Present.ly etc.) }\end{array}$ & 5,2 & 7,4 & 7,9 & $+2,7$ \\
\hline $\begin{array}{c}\text { websites with multimedia content (YouTube, Flickr, } \\
\text { Picassa, SlideShare, etc.) }\end{array}$ & 11,1 & 13,4 & 14,1 & +3 \\
\hline $\begin{array}{c}\text { knowledge exchange tools (Wikipedia, PBWiki, } \\
\text { Google Docs) }\end{array}$ & 19,1 & 12,8 & 12,9 & $-6,2$ \\
\hline
\end{tabular}

Source: formed on the basis of ( Statistical Book of Ukraine, 2018).

In terms of data (Table 5), the positive dynamics of the use of computers, computer networks, the Internet, including social media, is monitored: by $11 \%$ social networks (Facebook, LinkedIn, Xing, Viadeo, Yammer, etc.) from $17.5 \%$ in 2015 to $28.5 \%$ in 2018. But the level of use of such knowledge exchange tools as Wikipedia, PBWiki, Google Docs decreased by $6.2 \%$ from $19.1 \%$ in 2015 to $12.9 \%$ in 2018 . This is due to the expansion of the mobile Internet access network and the use of mobile applications in smartphones.

Such data indicate a correlation interdependence between the level of use of digital technologies in the activities of enterprises, the level of formation of digital competencies of employees and the level of competitiveness of the industry in the market. As a result, an urgent issue is to create conditions for the introduction of innovative technologies to improve the digital competence of personnel, which in turn will contribute to the consistency of personnel at energy enterprises.

Taking this into account, the formation of human capital as a source for the development of innovations should be considered in the context of direct and indirect investments, as well as through the application of the diversity principle to technologies for the formation of a complex of human competencies within digitalization of various spheres of life.

Optimization of the management algorithm for the human capital of energy enterprises in the virtual space for the formation of digital competencies based on the Smart Grids work. Taking into account the variability of the organization of the personnel management system of enterprises, it is essential that within transformation of the human capital management system of energy 
enterprises, the application of process and project approaches to the organizational structure of enterprise management is complementary. The optimization process formation of human capital management as a result of horizontal and vertical hierarchical integration provides its gradual transformation through the use of technologies (methods) of project management.

The introduction of a project-based approach to organizing the structure of human capital management of energy enterprises within digitalization of business processes implies the development of innovative competencies among employees (time management, adaptability, emotional intelligence, creative and critical thinking, decision-making, delegation, leadership, etc.). Taking this into account, the use of innovative educational technologies for the formation of digital competencies of personnel should be considered as a component of the implementation of innovative organizational structures for personnel management at the enterprise. In addition, in the context of the assertion of the dominant positions of artificial intelligence, the desire of enterprise managers to minimize the costs of technology for personnel, it will be advisable to develop an appropriate mobile application (bot / chat bot) for the selection of training courses (technologies) for the formation of digital competencies.

In particular, criteria set of technologies for the enterprises personnel formation can be represented in the form of a vector objective function (L. V. Zaburanna., 2014 p. 51):

$$
F(X)=\left\{f_{1}(X), \ldots, f_{k}(X)\right\}, k=\overline{1, K}
$$

A wide range of technologies that are currently used at energy enterprises, as well as the repeatability of criteria for characterizing each of the technologies, indicate the need to group and integrate these indicators and the introduction of a unified optimization criterion. The calculation of such a criterion for the enterprise as a whole and for each technology in particular will help to make the choice of optimization technologies that will contribute to the best disclosure of the hidden abilities of employees and the implementation of the strategic goals of the enterprise.

In the context of this issue, we can take as a basis the problem of multi-objective optimization, which is written as a vector problem of mathematical programming (L. V. Zaburanna., 2014p. 51-52):

$$
\begin{gathered}
F(X)=\left\{f_{1}(X), \ldots, f_{k}(X)\right\} \max , k=\overline{1, K}, \\
g_{i}(X) \leq b_{i}, i=\overline{1, M}, \\
X \geq 0
\end{gathered}
$$

In total, in economic and mathematical modeling, the process of bringing criteria to a single scale and dimensionless form is called rationing (methods: replacing the absolute values of criteria with their dimensionless values or relative values of deviations from the optimal values of the criteria) (L. V. Zaburanna., 2014 p. 53-54).

The diagnostics results of the use level of technologies for personnel formation, used at energy enterprises, indicate a pronounced tendency to optimize the costs of activities related to the formation of human capital and, as a result, a low level of implementation of Smart Grids. As a consequence, there is the need to consider the aspect of the optimization-oriented use of personnel formation technologies, as well as the development of the structure of human resources as a basis for determining the differentiated career expectations of employees due to the application of an ability approach to personnel formation.

In turn, modern risk factors for the functioning of enterprises using information technologies make managers also search for tools to optimize financial resources (maximize income and minimize costs), namely, the optimization-oriented use of technologies for the formation of personnel at enterprises:

$$
\begin{aligned}
& f(X)=k_{i} x_{i} \rightarrow \max \\
& f(Y)=c_{j} y_{j} \rightarrow \min
\end{aligned}
$$


where $f(X)$ and $f(Y)$ are the functions of maximizing income $X$ and minimizing resource costs $Y ; x_{i}$ and $y_{j}$ - the number of factors $i$ and $j ; k_{i}$ and $c_{j}$ are the coefficients of weighting $x_{i}$ and $y_{j}$ in achieving $f(X)$ and $f(Y)$.

Taking into account the relevance of the problematics and its applied nature, an appropriate algorithm has been developed, presented in the form of a block diagram and adapted to the peculiarities of the artificial intelligence work, which is(Figure 1), recommended for the development of a virtual (mobile) application (a bot as a digital software product) for smartphones, tablets, personal computers, which, in turn, will contribute to an increase in the level of consistency and involvement of personnel in the innovative development of an enterprise in the context of business processes digitalization and ensuring the launch of Smart Grids at energy enterprises, which, in turn, turn, will contribute to the transition to the consumption of green energy.

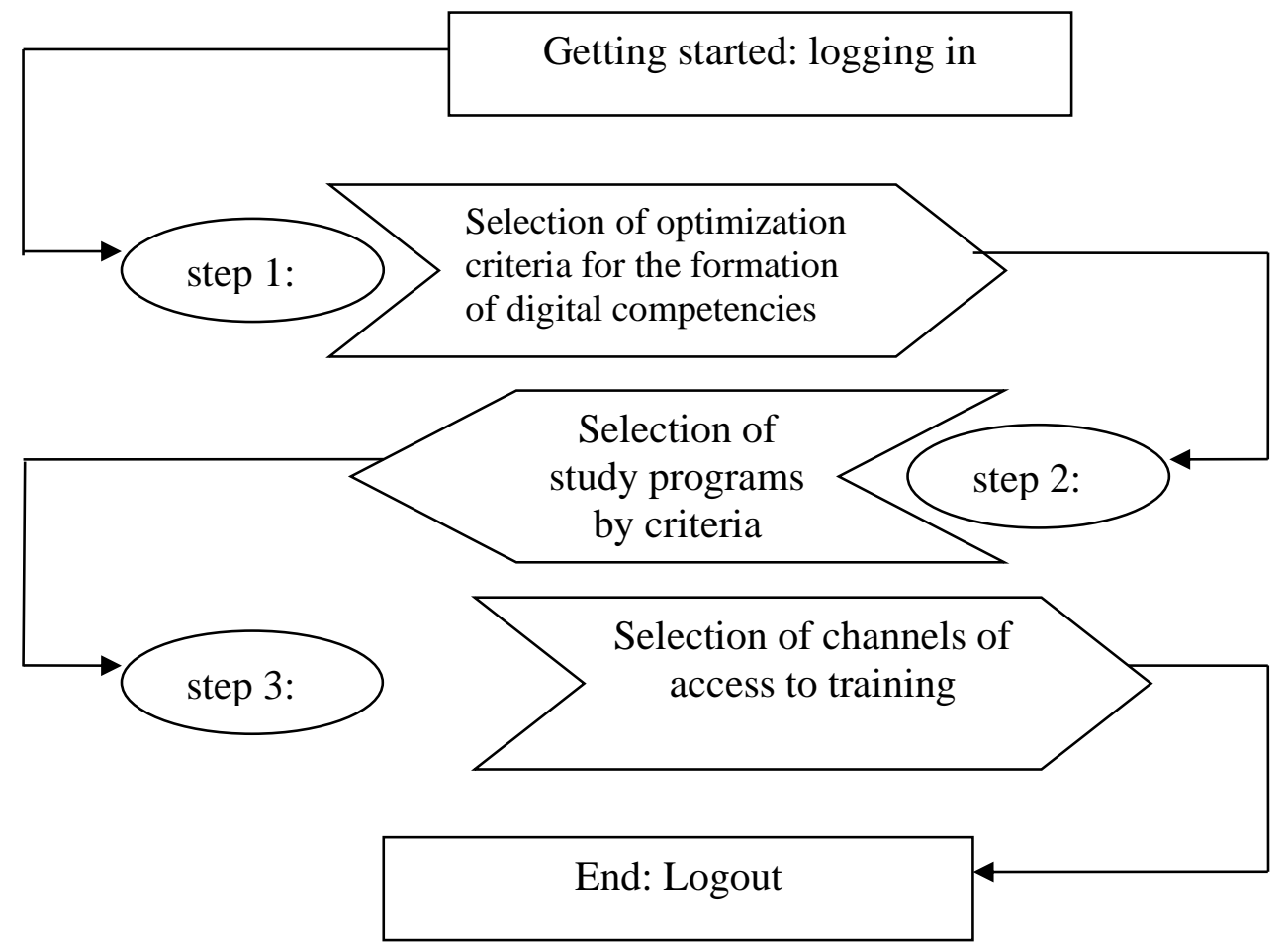

Figure 1. Algorithm for the virtual selection of educational programs for the formation of digital competencies

Source: author's development

In particular, the corresponding bot (chatbot) / mobile application called "Curricula (technologies) for the digital competency formation" can be developed according to the following algorithm (layout) of the virtual selection of educational programs/ curricula (technology), the formation of digital competencies of enterprises based on outsourcing (users: all categories of the population):

1) hosting, a kind of messenger (information resource) "Training programs for the formation ofdigital "competencies;

2) the user authorization;

3 ) the choice of optimization criteria, in particular, the definition of digital competencies, in which there is a need for formation (Table 6); 
4) reflection on the screen of the formed recommendatory list of educational programs according to the specified criteria;

5) recommended consulting sources of access to technologies for the formation of digital competencies.

In particular, the matrix of optimization criteria for the formation of digital competencies can be as follows:

$$
G=\left(\begin{array}{l}
g_{11} g_{12} \ldots g_{1 m} \\
g_{21} g_{22} \ldots g_{2 m} \\
\ldots \ldots \ldots . . . k_{n m}
\end{array}\right)
$$

where $n$ is a training course for the formation of digital competencies, $\mathrm{m}$ - optimization criteria, i.e. digital competencies.

In turn, the matrix of training courses for the formation of digital competencies $E$ is:

$$
E=\left(\begin{array}{l}
e_{11} e_{12} \ldots e_{1 m} \\
e_{21} e_{22} \ldots e_{2 m} \\
\ldots \ldots . . t_{n m}
\end{array}\right)
$$

where $n$ - the areas of activity of energy enterprises operating on the basis of smart grids, $m$ - the corresponding digital competencies necessary for the implementation of smart grids.

The peculiarity of the selection of such training programs is that the mobile application will provide omnichannel (obtaining unified operational information on prices, assortment of thematic areas of training programs, conditions for training in various educational service providers) by enabling the user to choose a communication channel. At the same time, it has been noted that the proposed algorithm is universal in nature, because it is designed both for employers (enterprise management) and directly for an ordinary employee or job seeker, as well as a person who needs to improve or develop their digital competencies.

\section{Conclusions}

Achieving climate neutral development requires an innovative approach to managing the human capital of energy enterprises. The growing demand for green energy, including electricity, testifies the formation of environmental behaviour among energy consumers. In addition, the development of digital technologies expands the availability to consumption of precisely green energy by launching the operation of smart grids at energy enterprises. As a consequence, there is a need to develop digital skills in employees of energy companies by developing appropriate training programs to ensure the operation of smart grids.

\section{References}

Borysiak, O. (2017). Innovative trends and optimization of the role of personnel in the strategic development at agricultural enterprises. International Journal of Economics and Society. (Memphis, USA), 2(9), 33-38

Borysiak, O.V. (2017). Optimization approach to technologies of personnel formation of enterprises. Modern economic research: co-operation, banking, public administration in a decentralized environment: Proceedings of the International Scientific Conference (Kielce, Poland, September 26 ${ }^{\text {th }}$, 2017). Kielce, Poland: Baltija Publishing, 24-26

Brych, V., Manzhula, V., Borysiak, O., Liakhovych, G., Halysh, N., Tolubyak, V. 2020. Communication Model of Energy Service Market Participants in the Context of Cyclic Management City Infrastructure. 2020 10th International Conference on Advanced Computer Information Technologies (ACIT), Deggendorf, Germany, 678-681, doi: 10.1109/ACIT49673.2020.9208902.

Brych, V.Ya., Borysiak, O.V. (2017). Innovatsiini tekhnolohii formuvannia personalu pidpryiemstv $\mathrm{v}$ umovakh optymizatsiinoho rozvytku. [Innovative technologies for the 
personnel formation of enterprises in the context of optimization development] Naukovyi visnyk Uzhhorodskoho universytetu. Seriia "Ekonomika", 2(50), 172-179

Buchynska, T.M. (2019). Formuvannia universalnykh kompetentnostei liudyny v umovakh inkliuzyvnoho rozvytku svitovoho hospodarstva [Formation of universal human competencies in the context of inclusive development of the world economy] : avtoref. dys. ... kand. ekon. nauk : 08.00.02. Ternopil : TNEU, 20 p.

Enerhetychnyi balans Ukrainy. [Energy balance of Ukraine] URL: http://www.ukrstat.gov.ua/operativ/operativ2012/energ/en_bal/arh_2012.htm.

Filippetti, A., Guy, F. (2020). Labor market regulation, the diversity of knowledge and skill, and national innovation performance. Research Policy, 49(1), February, Article number 103867.https://www.sciencedirect.com/science/article/pii/S0048733319301866?vi a\%3Dihub

Global Talent Trends 2020 report. URL: https://business.linkedin.com/talent-solutions/blog/trendsand-research/2020/global-talent-trends-2020

Imagineering on augmented reality and digital twin for digital competence. International Journal of Information and Education TechnologyVolume 9, Issue 3, March 2019, P. 213-217. http://www.ijiet.org/show-111-1395-1.html

Infohrafichnyi dovidnyk «Enerhetyka Ukrainy». [Infographic guide "Energy of Ukraine"] URL: https://businessviews.com.ua/ru/get_file/id/the-infographics-report-energy-of-ukraine2020.pdf.

Informatsiina dovidka pro osnovni pokaznyky rozvytku haluzei palyvno-enerhetychnoho kompleksu Ukrainy za hruden ta 2019 rik (za faktychnymy danymy). [Information note on the main indicators of the development of industries of the fuel and energy complex of Ukraine for December and 2019 (according to actual data)] URL: https://menr.gov.ua/news/34623.html.

Investytsiini prohramy PrAT «Lvivoblenerho». [Investment programs of PJSC "Lvivoblenergo"] URL: http://loe.lviv.ua/ua/korp_information.

Investytsiini prohramy PrAT «Rivneoblenerho». [Investment programs of PJSC "Rivneoblenergo"] URL: https://www.roe.vsei.ua/invest-program.

Investytsiini prohramy VAT «Ternopiloblenerho». [Investment programs of OJSC "Ternopiloblenergo"] URL: https://www.toe.com.ua/index.php/2012-08-30-07-29-28.

Kachaňáková, A., Nachtmannova, O, and Joniakova, Z. (2011). Personálny manažment, 2 vydanie, Bratislava : EKONÓMIA.

Kontseptsiia «zelenoho» enerhetychnoho perekhodu Ukrainy do 2050 roku. [Concept of Ukraine's green energy transition by 2050] URL: https://menr.gov.ua/news/34424.html.

Latent innovation in local economies. Research PolicyVolume 49, Issue 2, March 2020, Article number 103909.

https://www.sciencedirect.com/science/article/pii/S0048733319302276?via\%3Dihub

Lokhandwala M., HuaCai. Siting charging stations for electric vehicle adoption in shared autonomous fleets. Transportation Research Part D: Transport and Environment. Volume 80, March 2020, $102231 . \quad$ URL: https://www.sciencedirect.com/science/article/pii/S136192091930416X?via\%3Dihub

Mariachiara Barzotto, Lisa De Propris.Skill up: Smart work, occupational mix and regional productivity. Journal of Economic Geography, Volume 19, Issue 5, September 2019, Pages 1049-1075, https://doi.org/10.1093/jeg/lby050. URL: https://academic.oup.com/joeg/articleabstract/19/5/1049/5210029? redirectedFrom=fulltext https://eufordigital.eu/uk/thematic-area/eskills.

Merkevicius, J., Davidaviciene, V., Raudeliuniene, J., and Buleca, J. (2015) Virtual organization: specifics of creation of personnel management system. Ekonomie a Management, 18 (4), 200-211. Retrieved from http://www.ekonomiemanagement.cz/download/1449656512_51e6/14_VIRTUAL+ORGANIZATION+SPECIF ICS+OF+CREATION.pdf

Nanayakkara, S.M., Wickramasinghe, V., Samarasinghe, G.D. (2018). Role of strategic emotional intelligence on technological capability, technological knowledge management and 
organisational learning growth MERCon 2018 - 4th International Multidisciplinary Moratuwa Engineering Research Conference27 July, Article number 8421992, Pages 2942994th International Multidisciplinary Moratuwa Engineering Research Conference, MERCon 2018; Civil Engineering Complex, University of MoratuwaMoratuwa; Sri Lanka; URL :https://ieeexplore.iee.org/document/8421992

Navyky-2020, v yakykh naibilshe potrebuiut kompanii. [The 2020 Skills Companies Need Most] URL: $\quad$ https://theoryandpractice.ru/posts/17830-navyki-2020-v-kotorykh-kompaniinuzhdayutsya-bolshe-vsego

Optymizatsiini metody ta modeli : pidruchnyk / L. V. Zaburanna ta in. K. : TsP "Komprynt", 2014. 372 s. [Optimization methods and models] URL: https://nubip.edu.ua/sites/default/files/u104/\%D0\%9F\%D1\%96\%D0\%B4\%D1\%80\%D1\% 83\%D1\%87\%D0\%BD\%D0\%B8\%D0\%BA_18.pdf.

Prohrama EU4Digital. [Programme EU4Digital]

Statystychnyi zbirnyk Ukrainy 2018 [Statistical Book of Ukraine 2018]: https://ukrstat.org/uk/druk/publicat/kat_u/publ1_u.htm

The European Green Deal. URL: https://ec.europa.eu/info/sites/info/files/european-green-dealcommunication_en.pdf.

The new direction of technological change in the global economy. Structural Change and Economic DynamicsVolume 52, March 2020, Pages 1-12. https://www.sciencedirect.com/science/article/pii/S0954349X18304223?via\%3Dihub

Trushkina, N.V. Hlobalni tendentsii rozvytku elektronnoi komertsii [Global trends in the development of e-commerce] URL: http://economtoday.ukraine7.com/t20-topic

Van Der Kam, M. Peters, A.,Van Sark, W., Alkemade, F. (2019). Agent-based modelling of charging behaviour of electric vehicle drivers JASSS. Volume 22, Issue 4, October, Article number 7. http://jasss.soc.surrey.ac.uk/22/4/7.html

Vveinhardt, J., Minkute-Henrickson, R. (2015). Transformation of a learning organization into a smart organization : expansion of human resource by intellectual capital. Proceedings of EDULEARN15 Conference 6th-8th July 2015. Barcelona, Spain, 172-181. URL: http://s3.amazonaws.com/academia.edu.documents/38574641/Vveinhardt_Minkute_Henri ckson_Transformation_of_a_learning_organization_into_a_smart_organization.pdf?

Zvarych, R.Y. (2018). Ekonomichni imperatyvy protsesiv alterhlobalizatsii [Economic imperatives of alternative globalization processes]: dys. ... d-ra ekon. nauk : 08.00 .02 ; Ternopil. nats. ekon. un-t. Ternopil, $480 \mathrm{p}$. 